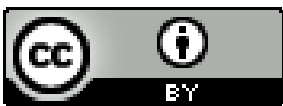

\title{
RELIGIOSIDADE AFRO-BRASILEIRA: DESAFIOS E PARADOXOS EM ACARAPE, CEARÁ, BRASIL
}

\author{
Antônio Roberto Xavier ${ }^{1}$ \\ Maria do Socorro Lopes da Silva ${ }^{2}$ \\ Edilberto Cavalcante Reis ${ }^{3}$
}

\begin{abstract}
Resumo: Busca-se demonstrar uma situação de invisibilidade da cultura afro-brasileira quanto ao aspecto religioso resultante do legado preconceituoso e eurocêntrico presente na formação da sociedade brasileira. Metodologicamente trata-se de um estudo de caso, com abordagem qualitativa, com emprego de técnicas de observação, recurso imagético e entrevista para coleta e geração de dados e informação. Evidencia-se a importância de se estudar e propagar as questões religiosas envolvendo religião de legado afro-brasileiro, pois, se constata a necessidade de se reconhecer e preservar o patrimônio simbólico pertinente à Umbanda. Percebe-se ser necessário o debate reflexivo e valorativo sobre o sentido social da cultura religiosa de matriz africana, afro-brasileira e afrodescendente. Emergiu desta escrita um pouco dos sujeitos que contribuíram e ainda contribuem para que a cultura religiosa de matriz africana se mantenha viva, ainda que sejam desconhecidas suas origens por tantos religiosos que se dizem praticantes.
\end{abstract}

Palavras-chave: Religiosidade. Umbanda. Cultura. Patrimônio Imaterial.

\section{AFRO-BRAZILIAN RELIGIOUSITY: CHALLENGES AND PARADOXES IN ACARAPE, CEARÁ, BRAZIL}

\begin{abstract}
We seek to demonstrate a situation of invisibility of Afro-Brazilian culture regarding the religious aspect resulting from the prejudiced and Eurocentric legacy present in the formation of Brazilian society. Methodologically it is a case study, with a qualitative approach, employing observation techniques, imagery and interviews to collect and generate data and information. The importance of studying and propagating religious issues involving Afro-Brazilian legacy religion

\footnotetext{
${ }^{1}$ Doutor e Pós-doutor em Educação pela Universidade Federal do Ceará. Docente Permanente do Mestrado Acadêmico em Sociobiodiversidade e Tecnologias Sustentáveis (MASTS), da Universidade da Integração Internacional da Lusofonia Afro-Brasileira (Unilab). E-mail: roberto@unilab.edu.br

${ }^{2}$ Mestra em Sociobiodiversidade e Tecnologias Sustentáveis pela Universidade da Integração Internacional da Lusofonia Afro-Brasileira. Professora da Educação Básica em Acarape-CE. E-mail: socorrolopes.mi@gmail.com

${ }^{3}$ Doutor em História Social pela Universidade Federal do Rio de Janeiro. Docente Permanente do Mestrado Interdisciplinar de História e Letras (MIHL), da Universidade Estadual do Ceará (UECE). E-mail: edilberto.reis@uece.br
} 
is evidenced, since it is necessary to recognize and preserve the symbolic heritage pertinent to Umbanda. It is perceived to be necessary the reflective and evaluative debate about the social meaning of the religious culture of African, Afro-Brazilian and African descent. From this writing emerged some of the subjects who contributed and still contribute to keep the religious culture of African matrix to stay alive, even though its origins are unknown by so many religious who claim to be practitioners.

Keywords: Religiosity. Umbanda. Culture. Intangible Heritage

\section{RELIGIOSIDAD AFRO-BRASILEÑA: DESAFÍOS Y PARADOJAS EN ACARAPE, CEARÁ, BRASIL}

Resumen: Buscamos demostrar una situación de invisibilidad de la cultura afrobrasileña con respecto al aspecto religioso resultante del legado prejuicioso y eurocéntrico presente en la formación de la sociedad brasileña. Metodológicamente es un estudio de caso, con un enfoque cualitativo, que emplea técnicas de observación, imágenes y entrevistas para recopilar y generar datos e información. Se evidencia la importancia de estudiar y propagar cuestiones religiosas relacionadas con el legado afrobrasileño, ya que es necesario reconocer y preservar la herencia simbólica pertinente a Umbanda. Se percibe como necesario el debate reflexivo y evaluativo sobre el significado social de la cultura religiosa de ascendencia africana, afrobrasileña y africana. De este escrito surgieron algunos de los sujetos que contribuyeron y aún contribuyen a mantener viva la cultura religiosa de la matriz africana, a pesar de que muchos religiosos desconocen sus orígenes y afirman ser practicantes.

Palabras clave: Religiosidad. Umbanda Cultura. Patrimonio inmaterial

\section{RELIGIOUSITÉ AFRO-BRÉSILIENNE: DÉFIS ET PARADOXES À ACARAPE, CEARÁ, BRÉSIL}

Résumé: Nous cherchons à démontrer une situation d'invisibilité de la culture afro-brésilienne en ce qui concerne l'aspect religieux résultant de l'héritage préjugé et eurocentrique présent dans la formation de la société brésilienne. Méthodologiquement, il s'agit d'une étude de cas, avec une approche qualitative, utilisant des techniques d'observation, des images et des entretiens pour collecter et générer des données et des informations. L'importance d'étudier et de propager les questions religieuses impliquant l'héritage religieux afro-brésilien est mise en évidence, car il est nécessaire de reconnaître et de préserver le patrimoine symbolique pertinent pour l'Ombanda. Il est perçu comme nécessaire le débat réflexif et évaluatif sur la signification sociale de la culture religieuse d'origine africaine, afro-brésilienne et africaine. De cette écriture ont émergé certains des sujets qui ont contribué et continuent de contribuer à maintenir la culture religieuse de la matrice africaine pour rester en vie, même si ses origines sont inconnues par tant de religieux qui prétendent être des pratiquants.

Mots-clés: Religiosité. Umbanda. Culture. Patrimoine immatériel.

\section{INTRODUÇÃO}

O debate mais amplo e diverso sobre religiosidade tem ganhado destaque em diferentes aspectos nos últimos tempos. A discussão mais profícua acerca das questões 
religiosas tem se aprofundado sobretudo por uso e por meio da grande mídia. Ao mesmo tempo, tem ocorrido maior abertura para debates e reflexões também nas instituições de ensino superior com foco maior na valorização e respeito à pluralidade, às diferenças e à diversidade.

No tocante a essa temática, a região Nordeste é um mosaico cultural com ascendência indígena, africana e europeia. As memórias coletivas se acendem inegavelmente nesse cenário, na perspectiva de um olhar envolvendo as questões religiosas.

Nestas décadas iniciais do século XXI, importantes avanços têm ocorrido principalmente na construção das identidades do povo, que se constituem por meio de um conjunto social e cultural de experiências vivenciadas e/ou experimentadas. Essa trajetória se inicia no seio familiar e na educação formal e progride no ambiente de trabalho.

Este artigo se assenta na perspectiva dos estudos sobre a história de sujeitos construtores de sua própria história, mas que não se firmam reconhecidamente como cidadãos de identidades descendentes de uma miscigenação e religiosidade livres, pela falta de conhecimento e/ou reconhecimento de nossos ancestrais com relação à tradição entre os povos que aqui se misturaram e construíram seu arcabouço cultural. Tal riqueza de manifestações culturais historicamente formou-se pela influência do povo africano. Dessa forma, os pressupostos justificadores deste artigo partem de uma vivência no contexto para compreender as razões das manifestações religiosas que transitam nas gerações.

Metodologicamente trata-se de um estudo de caso com abordagem qualitativa, recorrendo à observação, às imagens e sobretudo ao emprego da entrevista como técnicas de coleta e geração de dados. Para Lakatos e Marconi (1994, p. 195), no caso da entrevista:

[...] o entrevistado discorre sobre o tema proposto com base nas informações que ele detém e que no fundo são a verdadeira razão da entrevista [...]. A entrevista é um encontro entre duas pessoas, a fim de que uma delas obtenha informações a respeito de determinado assunto, mediante uma conversação de natureza profissional. 
Dessa forma, buscou-se trazer a reflexão e a discussão de uma situação de invisibilidade religiosa afro-brasileira resultante de uma herança miscigenada dos sujeitos afro-brasileiros os quais sempre foram excluídos no campo das ideias e no meio social na conjuntura nacional, regional e local.

\section{O LEGADO ESCRAVOCRATA NA CIDADE DE ACARAPE, CEARÁ}

A cidade de Acarape está localizada ao norte do Ceará e faz parte da região do Maciço de Baturité, que “[...] destaca-se no semiárido quente do Ceará por apresentar clima ameno, abundância de atrativos naturais como flora, fauna, riachos, quedas d'água, fontes de água mineral, além de um dos raros vestígios de Mata Atlântica existente no interior nordestino" (MARTINS, 2011, p. 21).

O município de Acarape fica a cerca de 56 quilômetros da capital do Estado do Ceará, Fortaleza, num percurso realizado pela rodovia CE-060. Limita-se com os seguintes municípios: Guaiúba, ao norte; Barreira, ao sul; Pacajus, ao leste; Redenção, ao oeste (SAMPAIO FILHO, 2003).

As terras da região entre os sopés do Maciço de Baturité e a serra do Cantagalo, ao redor das margens do rio Pacoti (também conhecido como rio Acarape), eram habitadas por diversas etnias, como: Potiguara, Jenipapo, Kanindé, Choró e Quesito, terras as quais receberam, a partir do século XVII, diversas expedições militares e religiosas (GOMES, 2012; XAVIER; VASCONCELOS, 2018).

Com a implementação da pecuária no Ceará no século XVIII, as terras de Acarape também foram beneficiadas com a agricultura da cana-de-açúcar devido à fertilidade do solo e à abundância de água. Nesse contexto, surgiu a localidade de Calaboca da Vila de Redenção, que se define como centro urbano com a construção da Companhia Cearense da Via Férrea de Baturité S.A. Com a prosperidade do comércio e da agricultura da canade-açúcar e a abastança de água, foram criados engenhos e alambiques no município, no qual vieram trabalhar escravos africanos (JUCÁ NETO, 2012).

Acarape, na língua tupi, significa "dos acarás” e, em sua variação toponímica, "Acara- Pe", significa caminho dos acarás, canal do peixe ou caminho das garças. Primitivamente o nome "Acarape" designava a sede do município, hoje Redenção. O 
então povoado chamava-se Calaboca. Porém, com o pioneirismo do município subordinante, que se destacou como primeira cidade do Ceará a libertar os escravos, houve-lhe por outorga honorária o nome de "Redenção", que significa "a redentora, libertadora", e, por sua vez, o modesto povoado de Calaboca, em homenagem às suas origens, passou a chamar-se Acarape (SAMPAIO FILHO, 2003; SILVA, 2002).

No ano de 1926, precisamente em 18 de setembro, sob a Lei ${ }^{\circ} 2.376$, Calaboca foi elevado à categoria de vila, em virtude de seu crescimento populacional e comercial. O povoado recebeu o benefício de ser responsável pela ferrovia Fortaleza-Baturité. Esse benefício constou da estação ferroviária construída pela companhia, sendo inaugurada em 26 de outubro de 1879. Essa companhia facilitou, além do comércio local, idas e vindas dos senhores de escravos, que transportavam negros (escravos) para trabalharem em suas lavouras; servindo também para a locomoção de pessoas "comuns".

Já com a denominação atual, passou à categoria de município sob a Lei $\mathrm{n}^{\circ}$ 11.308, de 15 de abril de 1987. Dentre os municípios destacados na região, Acarape está mais próximo da capital do estado, cortado pela CE-060.

\section{DO CENÁRIO RELIGIOSO ATUAL EM ACARAPE}

Entre os povos, a religião é fator determinante da vivência cultural. A sociedade oferece uma diversidade de religiões, resultado de uma mistura e de várias acomodações históricas. Portanto, a religião é uma das áreas da vida social e da cultura popular que se conservaram ao longo do processo histórico. Em outras palavras, "No Brasil, da mesma forma como ocorre em outros países de forte tradição cristã, as crenças e práticas propostas pela estrutura religiosa formal têm sido progressivamente reinterpretadas pelo povo à luz de experiência quotidiana concreta" (GASPAR, 2004, p. 123).

Esse cerne religioso geralmente é adquirido através das gerações passadas como sabedoria, sendo tradicionalmente a oralidade o mecanismo usado. Dessa forma, a ação de transmitir os conhecimentos faz com que as vivências e as experiências estejam sempre em evidência, revivendo e reafirmando, assim, a sua identidade e consolidando o sentimento de pertença de uma coletividade (CASTELLS, 1999; XAVIER; MACHADO, 2017). 
Há uma predominância religiosa do catolicismo, seguido de perto pelos grupos evangélicos. O município de Acarape tem como programação cultural as festas religiosas: Festa do Padroeiro São João Batista (24 de junho, feriado municipal), realizada com duração de nove noitadas, com a diversificação de padres de outras paróquias e procissões, encerrando-se com um grande rifão para angariar fundos. Também é comemorado o trido (três dias) da Festa de São João Batista (no mês de agosto, apenas no final de semana). Comemora-se o nascimento do precursor em junho e o martírio em agosto. São modos de assumir uma relação "peregrina" com o tempo, o espaço, o corpo e a dimensão coletiva (SANCHIS, 2001).

Buscar o sagrado em forma de peregrinação, repetindo seus ritos, é crer no mundo santificado. Aos domingos dedicados ao Senhor, grande parte da comunidade participa das celebrações, sendo a cada domingo um grupo responsável pela parte litúrgica, inclusive um dos domingos é de responsabilidade dos africanos; além da liturgia, há o canto coral, em que usam a língua crioula.

\section{ACHADOS, PROCEDIMENTOS E RESULTADOS DA PESQUISA}

Realizaram-se entrevistas com alguns sujeitos do município buscando desvelar das pessoas envolvidas no contexto religioso suas opiniões e as influências das matrizes africanas. O primeiro entrevistado foi o líder religioso, o vigário (2018), que assim se expressou: "Eu vejo com o olhar de Deus, não discriminar quem é branco, negro, quem veio da África, do Iraque; o olhar de Jesus é com a igualdade, a partilha e o acolhimento, pois somos todos irmãos". O acolhimento reflete não só a sociabilidade de um determinado grupo, mas a sensibilidade no sentido de agregar pessoas, quer seja para o refúgio, alento ou agradecimento. No tocante a isso, Lemos (2008 apud OLIVEIRA, 2011, p. 256), afirma: “[...] sentido para a vida na experiência do sagrado, e é nele também que encontram explicações para seus sucessos e/ou fracassos".

A igreja católica, nas suas atribuições caracterizadas por ações de catequese, legitima práticas através dos sacramentos, como reforçou o vigário (2018):

Primeiro eles chegam com uma carta do vigário deles, apresentando o que eles faziam, logo após muitos são preparados pelos catequistas, que também são africanos e recebem os sacramentos e são evangelizados para serem discípulos;

Revista da ABPN • v.12, $\mathrm{n}^{\mathrm{o}} 32 \cdot$ março - maio 2020, p. 252-268 
não há nenhum empecilho, isso é amor de Deus, a igreja é um leque, um livro aberto para todas as pessoas. Jesus acolhe e é assim que devemos fazer.

As manifestações religiosas passam da igreja para o templo sagrado, que é o filho de Deus; após o rito do sacramento, torna-se um cristão.

[...] um rito produz estados mentais coletivos suscitados pelo fato de um grupo estar reunido. $\mathrm{O}$ essencial é que haja indivíduos reunidos, que sentimentos comuns sejam experimentados e expressos em atos comuns. Tudo nos leva então à mesma ideia: os ritos são, antes de tudo, os meios pelos quais o grupo social se reafirma periodicamente (SEGALEN, 2002, p. 23-24).

A cultura dos afro-brasileira na dimensão religiosa é viva no contexto social brasileiro, pois lhe está arraigada e entranhada, já que os brasileiros são frutos de uma miscigenação, os quais, porém, são preconceituosos, não porque assim o desejem, mas porque são vitimados por uma herança e por uma colonização desmedidas. Sobre isso, o vigário (2018) assim se posicionou:

O que eles frequentam não é religião; na verdade, não importa. São meios que eles criam; usam seu próprio pensamento, o que seu coração manda, porque Deus ensina qual o caminho a seguir. Ele disse: 'Eu sou o caminho, a verdade'. A igreja católica não prega o mal, não é proibido que esses lugares façam sua experiência, celebrem sua cultura, mas será se esses lugares praticam o bem ou o mal? Não estamos aqui para julgar e condenar ninguém, então Jesus pede que obedeça aos mandamentos: 'Amar a Deus sobre todas as coisas e amar ao próximo como a si mesmo'. Se cada um não obedecer aos mandamentos de Deus, aí, sim, é contra a vontade de Jesus.

Nessa conjuntura de crenças, valores e princípios religiosos, existe uma dificuldade em compreender e aceitar essas incompatibilidades de convicções, talvez saberes e conhecimentos. A seguir há algumas fotos do recebimento do batismo e da participação direta de um africano servindo no altar.

Figura 3 - Missa com batismo dos africanos 


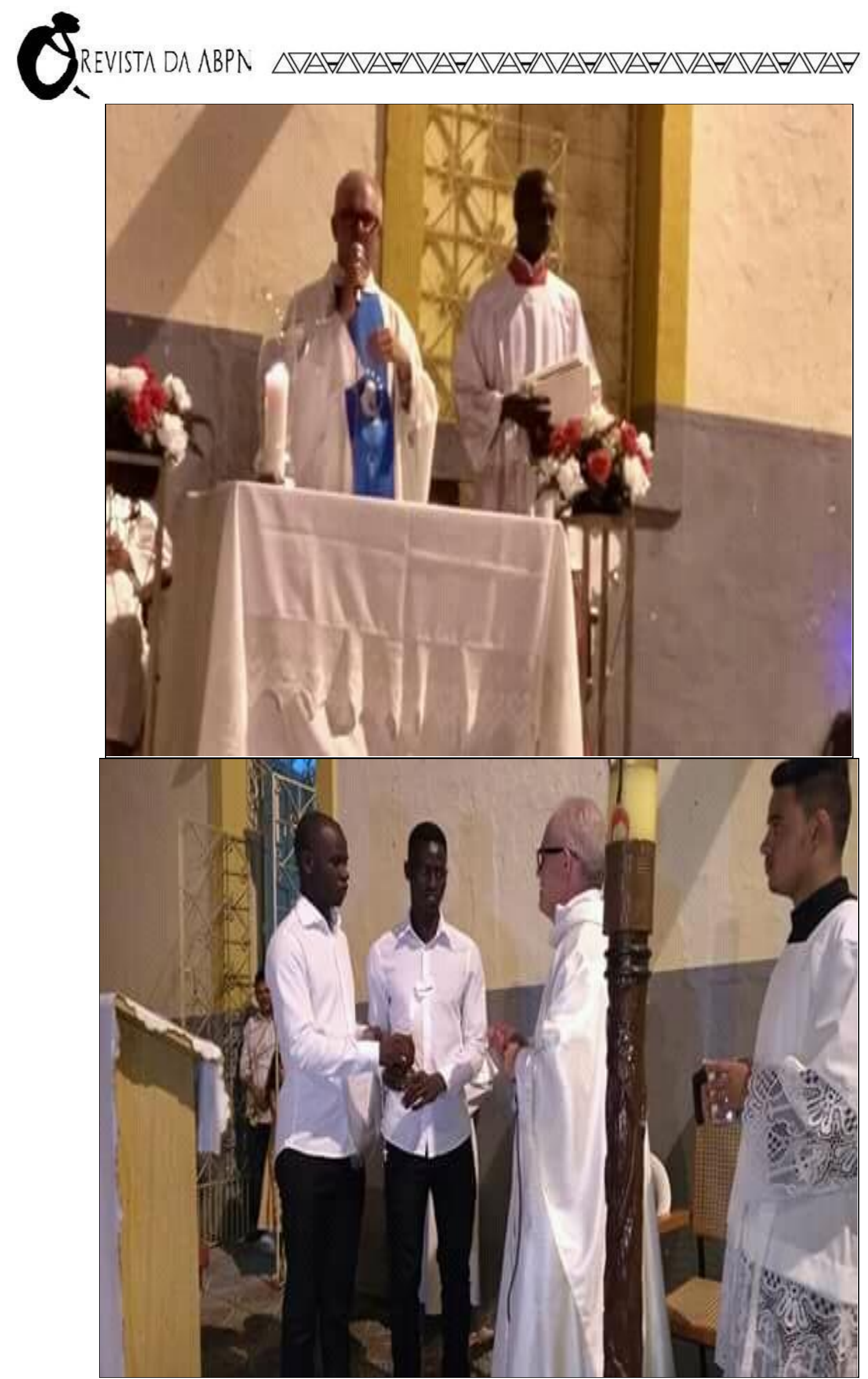

Fonte: Acervo digital dos autores (2019). 
Com essa relação participativa dos fiéis africanos na religião, é possível perceber a necessidade da sua procura constante de equilíbrio e de fortalecer o espírito através dos ritos sagrados. Numa outra doutrina, a comunidade dos evangélicos (protestantes), que também detém grande parte da população, possui diversas igrejas com denominações diferentes distribuídas na cidade, dentre elas a adventista, acolhedora também de grande parte dos africanos. Aos domingos, vê-se nitidamente a divisão dos cristãos se dirigindo às referidas igrejas. Ao se perguntar ao diretor da igreja adventista pesquisado (2019), inclusive africano natural de Angola, em relação ao objetivo da acolhida dos africanos na igreja e a participação nos ministérios, ele assim se manifestou:

Me tornei adventista em setembro de 2016, após muitos estudos e participação, toda a igreja se reúne e nomeiam o diretor. Foi unânime a votação. Grande parte dos africanos já congregavam em seus países de origem, visitantes e convidados também, muitos estudantes de Guiné-Bissau, Angola, São Tomé, Cabo Verde, Moçambique. Temos uma percepção clara: somos todos filhos de Deus.

Dessa forma, pode-se constatar a participação dos africanos de distintos países e até mesmo a sua ascensão dentro da hierarquia religiosa da igreja. Corroborando esse posicionamento, Gaspar (2004, p. 123) assevera: "No Brasil, da mesma forma como ocorre em outros países de forte tradição cristã, as crenças e práticas propostas pela estrutura religiosa formal têm sido progressivamente reinterpretadas pelo povo à luz de experiência quotidiana concreta". Cada igreja mostra a fé e a fidelidade de seu povo nos princípios religiosos e na doutrina escolhida a seguir.

Ao ser indagado sobre os africanos receberem o batismo após a chegada no Brasil, o diretor (2019) assim se expressou: "Não necessariamente, grande parte já tinha o batismo de seu país de origem. Como é uma igreja a nível mundial, não muda nada. Temos os princípios, somos guiados pela Bíblia e temos um manual da igreja padronizado".

O sagrado é uma experiência que, após o contato e a fé ser despertada, não se desvirtua após os sacramentos. Para Puntel (2010), a igreja deve anunciar a mensagem de salvação mesmo dentro de uma sociedade cada vez mais envolta na lógica da velocidade, da globalização e da mídia. Para isso, é preciso contextualizar. Ou, segundo essa autora, é necessário discernir e renovar-se, bem como voltar a pensar na própria identidade: “[...] 
É necessário individualizar formas críveis para uma comunicação da fé em [um novo] contexto sociocultural, no qual o Evangelho deve se encarnar sem dispersar-se e sem anular-se. E isso faz parte da identidade da Igreja: a evangelização" (PUNTEL, 2010, p. $165)$.

Quando questionado sobre a cultura dos africanos da umbanda e candomblé e sobre o fato de muitos ainda continuarem frequentando a igreja, assim falou o diretor (2019): “Afirmo que 100\% não existe, sei que acontece em muitas outras religiões, mas na igreja adventista não, a gente vive os princípios da igreja adventista do sétimo dia; não podemos estar no hibridismo religioso".

Claro que seguir uma doutrina requer uma disciplina, porém vê-se a discriminação da própria cultura, pois as matrizes africanas sofreram ou ainda sofrem na atualidade perseguições que parecem ser oriundas de uma falta de conhecimento ou de um conceito negativo, mesmo vindo de um próprio africano.

Figura 4 - Culto na igreja adventista do sétimo dia

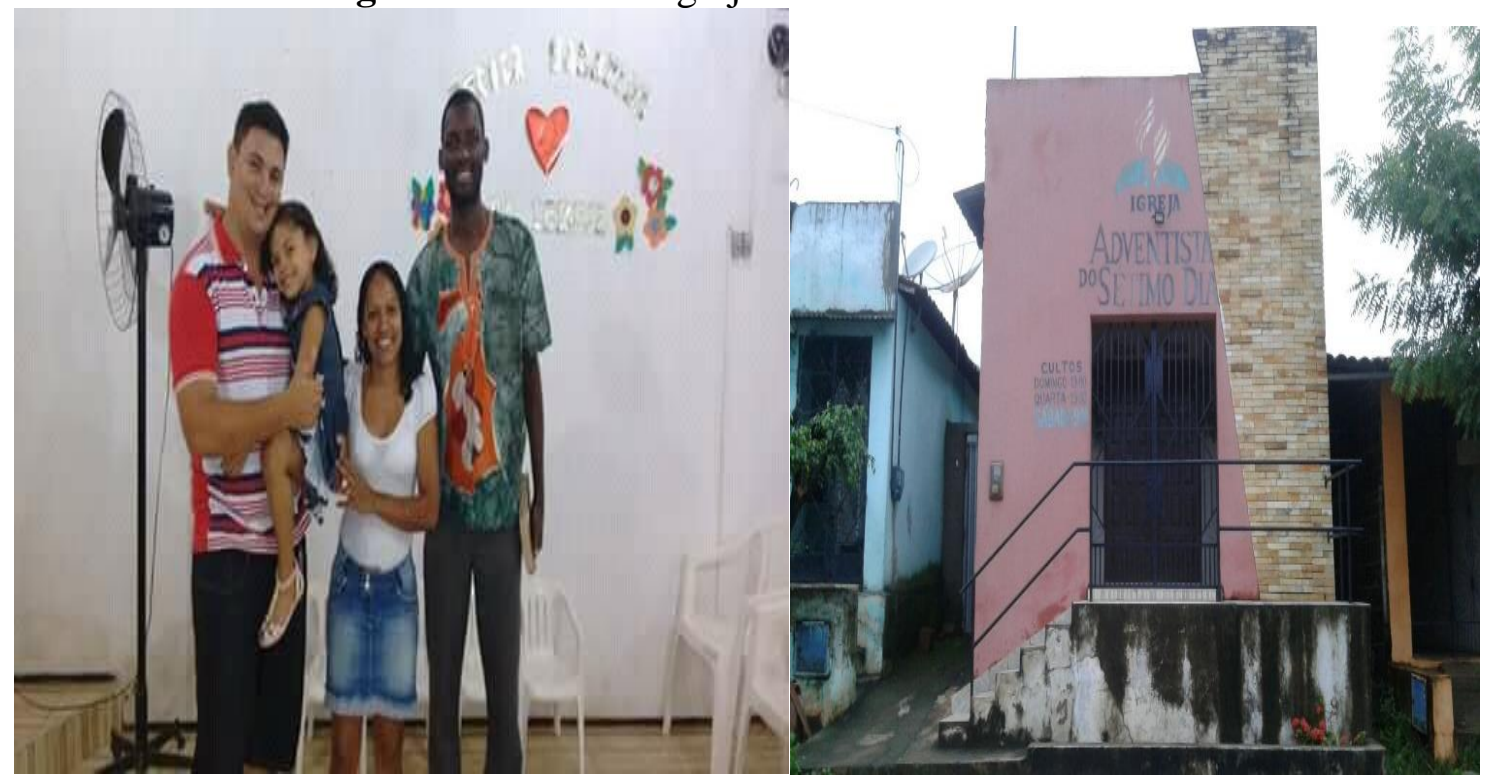

Fonte: Acervo digital dos autores (2019). 
A Cultura Evangélica (segunda sexta-feira do mês de setembro), é comemorada com culto no centro da cidade, sendo então feriado municipal; essa data foi criada há oito anos, na gestão anterior. Já o grande show ecumênico "Os Levitas" acontece no período carnavalesco (realizado a partir do ano de 2014, em uma iniciativa da atual administração, “Construindo o Novo Tempo"), o que é demonstrado nas fotos a seguir:

São três dias de competições entre bandas regionais e premiações e cantores de renomes denominados católicos e evangélicos. Pessoas de outras cidades e da própria comunidade participam fervorosamente, mas sendo a participação do público muito distinta entre católicos e evangélicos nas referidas noites. Além do movimento religioso, grande parte do movimento também se torna financeiro, pois promovem movimentos em barracas trazendo renda aos participantes.

Dentre as manifestações religiosas, há também os ritos das rezadeiras, que frequentemente são utilizadas através de suas rezas e curas, sendo muito prestigiadas pela comunidade católica. Dessa forma, as rezas e curas, na grande maioria, são realizadas nas crianças diagnosticadas com quebranto (mau-olhado). Também denominadas benzedeiras, vêm de uma tradição popular principalmente de baixo poder econômico. Historicamente essa cultura foi construída pela influência dos povos africanos e indígenas. "A utilização das benzeduras e das plantas como recursos divinatórios e naturais na luta contra as doenças foram herdadas dos portugueses, africanos e índios, no entanto é desenvolvida no Brasil com características próprias e peculiares" (SILVA, 2010, p. 35).

É possível, diante de alguns elementos fortes, reconhecer esse legado imaterial da cultura que deu origem a essa nação: é o caso, por exemplo, da tradição das rezadeiras e benzedeiras.

Existem rezadeiras e benzedeiras espalhadas por todo o país, nas grandes cidades e no interior, nas áreas urbanas e rurais. [...]. Geralmente esses benzedores utilizam apenas um conhecimento empírico sobre as ervas medicinais e a capacidade de usar sua intuição e força interior, sem qualquer compromisso com um rito religioso específico. Embora possa haver rituais de origem africana e ameríndia, o que predomina na benzedura é o apelo aos santos católicos a que a tradição popular atribui poderes de cura (GASPAR, 2004, p. 127). 
Os terreiros de candomblé e umbanda também existem na comunidade, muito antigos, os quais provavelmente sempre continuarão a existir. Frequentadores no anonimato, muitas vezes, procuram os terreiros no desespero pela falta de solução para algum problema, seja para a explicação de um problema familiar, seja para o tratamento de alguma doença inexplicável pela ciência. Nessa óptica, de acordo com Ortiz (1999, p. 16), “[...] a umbanda corresponde à integração das práticas afro-brasileiras na sociedade brasileira moderna; o candomblé significaria justamente o contrário, a conservação da memória coletiva africana no solo brasileiro".

Dessa forma, os adeptos dessa religião sofrem o preconceito oriundo dos demais membros da sociedade, por isso a ocultam, não tentam converter ninguém a ela e professam uma outra religião no contexto social. Consoante o entrevistado pai de santo (2019) do terreiro de umbanda localizado no bairro São Benedito, em Acarape: “A umbanda ainda é muito criticada, porque, às vezes, as pessoas levam para o lado obscuro. Alguns pais de santo que trabalham levam para esse lado ruim, mas, na verdade, não é; a religião umbanda é paz, amor e caridade".

Esse modo de vida, principalmente a religiosidade ao longo da história, remete ao africanismo, à busca identitária, a uma relação efetiva com o vivido e com o sagrado. $\mathrm{O}$ homem, nesse contexto, é a síntese de tudo que existe, o recipiente por excelência da força suprema e, ao mesmo tempo, aquele para quem convergem as forças existentes (DOMINGOS, 2015).

Nesse anseio de completude espiritual, muitas vezes de forma invisível, há a busca de pessoas de classes indistintas, permeadas nas camadas sociais, como revelou o pai de santo entrevistado (2019): “Costumam frequentar pessoas pobres, africanos, mas também de classe social mais elevada, porém, de forma oculta para a sociedade; existem os dias de gira aberta para quem quiser participar, olhar, receber os orixás; temos tudo legalizado".

Desde sua origem, na dialética entre o negro e o branco, a umbanda é vista socialmente como religião dos menos favorecidos economicamente; apesar dessa visão, são inúmeros os frequentadores de grande poder aquisitivo. Segundo Ortiz (1999), assim ela prossegue, atraindo cada vez mais adeptos, médiuns e assistentes desse nível social, embora seja mais comum encontrar tendas em bairros mais populares. 
Esse cenário diversificado, ora frequentado e visto como profano, ora visto como sagrado, retrata um arcabouço curioso de legitimidade e de afirmação cultural africana, que conquista, acolhe e, acima de tudo, respeita. O pai de santo (2019) ainda enfatizou: “A nossa religião não se importa que a pessoa frequente outras religiões, o que importa é que venha, assista e participe. São vários santos católicos que usamos na umbanda, como: São Cosme Damião, São Jorge, Santa Bárbara e outros”.

Consoante as palavras supracitadas, percebe-se que o homem é marcado pela forma como busca explicar sua vida; ele faz do meio, com rituais durante as festas, uma prolongação do espaço sagrado, como destacam as fotos a seguir: imagens dos santos de um dos terreiros de umbanda.

Figura 6 - Imagens dos santos de um dos terreiros de umbanda
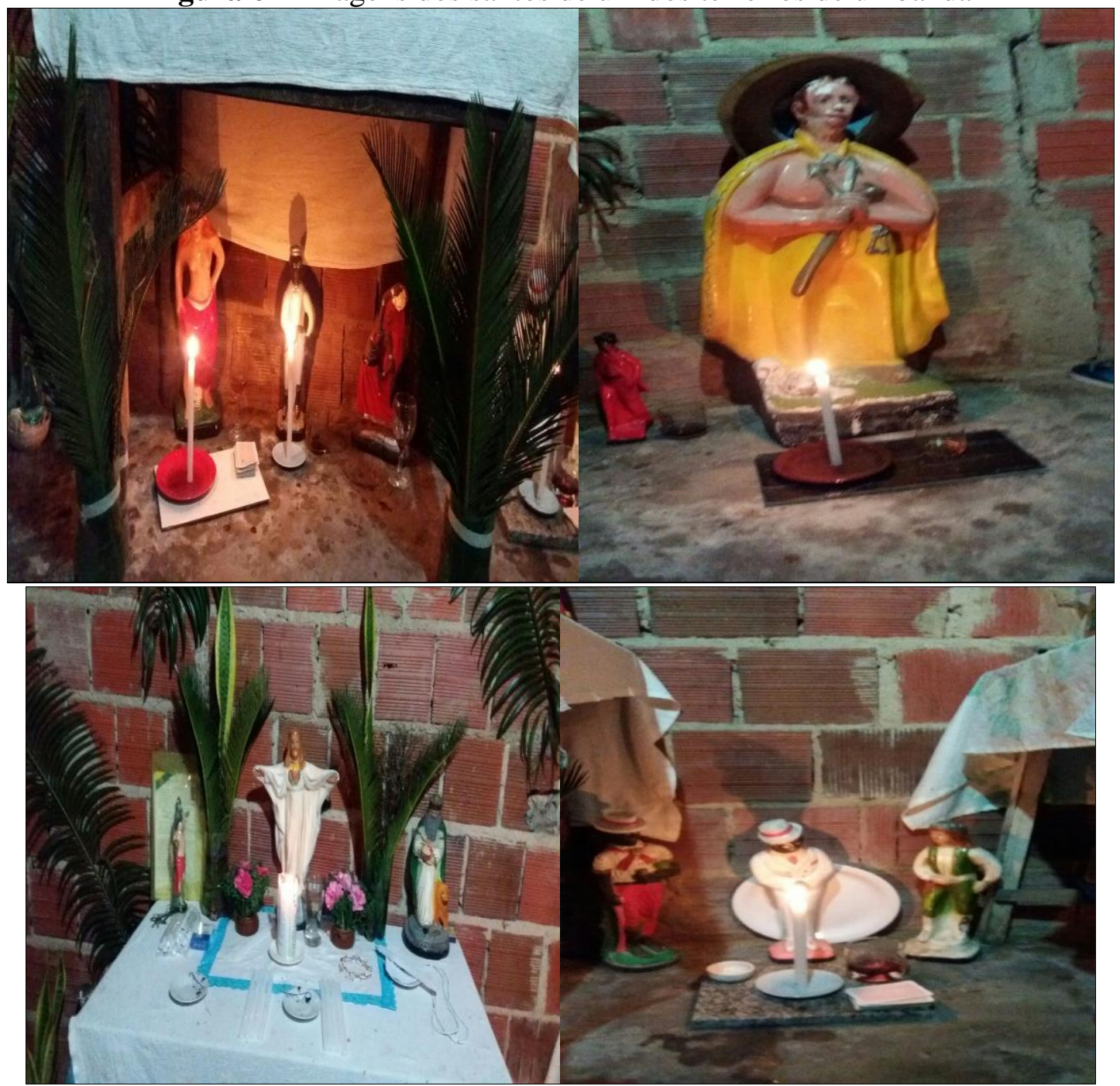

Fonte: Acervo digital dos autores (2019).

Revista da ABPN • v.12, $\mathrm{n}^{\mathrm{o}} 32 \cdot$ março - maio 2020, p. 252-268 
Percebe-se claramente nas imagens os santos que também são cultuados na religião católica, havendo a manifestação do sagrado e uma necessidade de acolher um público de forma diferenciada e heterogênea, mesmo que vivencie uma participação sem a percepção da origem e dos objetivos da religião afro: "O sincretismo valeu como uma poderosa arma que de início os negros habilmente manejaram contra a pressão esmagadora da cultura superior dos povos escravizadores" (SANCHIS, 2001, p. 69).

A inteligência dos negros em camuflar e cultuar as imagens católicas, mas invocando os deuses de sua religião africana, ainda hoje é muito forte na sociedade brasileira, dependendo da região do país.

Quadro 2 - Cinco principais orixás e seus concernentes santos católicos

\begin{tabular}{|c|c|c|}
\hline Orixá & Católico & Definição \\
\hline Oxalá & Jesus & $\begin{array}{c}\text { Oxalá é a divindade que criou a } \\
\text { humanidade. }\end{array}$ \\
\hline Iansã & Santa Bárbara & $\begin{array}{c}\text { Esposa de Xangô; é a deusa dos } \\
\text { raios, dos ventos e das } \\
\text { tempestades. }\end{array}$ \\
\hline Xangô & São Jerônimo e São João & $\begin{array}{c}\text { Xangô é o deus do trovão e da } \\
\text { justiça. }\end{array}$ \\
\hline Iemanjá & $\begin{array}{c}\text { Nossa Senhora da } \\
\text { Conceição }\end{array}$ & $\begin{array}{c}\text { Iemanjá é a deusa dos grandes rios, } \\
\text { mares e oceanos. }\end{array}$ \\
\hline Ogum & Santo Antônio e São Jorge & $\begin{array}{c}\text { Ogum é o orixá da guerra, capaz de } \\
\text { abrir caminhos na vida. }\end{array}$ \\
\hline
\end{tabular}

Todo esse arcabouço religioso, juntamente com seu aparato performático, expressa os resquícios africanos arraigados na cultura nacional que caracterizam uma continuidade e estabelecem, de forma efetiva, a identidade cultural do povo. Mesmo diante desse silenciamento demonstrado, a tentativa de ignorância ao legado dos inúmeros representantes das nações africanas sequestrados e o não reconhecimento da nossa própria identidade dos nossos ancestrais são visivelmente expressos nas ações desenvolvidas, mesmo que inconscientemente, no cotidiano do contexto religioso dos munícipes de Acarape.

\section{CONSIDERAÇÕES FINAIS}


A sociedade brasileira caminha, em âmbito geral e local, em boa parte, sem saber ou reconhecer o significado e importância do patrimônio histórico-cultural, sobretudo representado nos simbolismos memoriais. As memórias conservadas no silêncio e ignoradas podem vir à tona e enriquecer a compreensão do processo de formação histórica de sujeitos sociais. Fazer uma relação entre religião/cultura e memória/história é um importante vetor para se reconhecer como ser social, olhando para o passado e estudando o desenrolar histórico a partir do presente para a preservação do patrimônio imaterial a ser legado às futuras gerações.

Os desafios e paradoxos a serem encarados e/ou superados no tocante a invisibilidade, discriminação e preconceito com relação á práticas religiosas afrobrasileiras são muitas e enraizados na gênese de formação da sociedade brasileira. Isto porque, muitas vezes, tais males residem nas formas conservadoras e tradicionais de se praticar a religiosidade no país devido ao longo período de hegemonia de religiões de ideologias eurocêntricas.

Os entraves visando desbancar tal legado preconceituoso e discriminador religioso, nem sempre é consenso, pois se apresenta nos meandros cognitivos perpassados didáticos-pedagogicamente desde os idos coloniais. A procura de nossa ancestralidade, a efetividade intercultural, interdisciplinar, o respeito, a integração e aprendizagem com as diferenças, reconhecendo o legado cultural religioso afrobrasileiro tem sido e continua uma peleja, inclusive nas composições curriculares de nossas instituições de ensino.

A assertiva, através deste estudo sobre o patrimônio o diverso, plural e religioso afro-brasileiro, aponta que o conhecimento, o reconhecimento e a preservação patrimonial não pode e não deve se limitar somente ao patrimônio material e/ou de pedra e cal, mas englobam a identidade étnico-cultural simbolizada nas reminiscências dos sujeitos sociais participantes e ativos da formação cultural do país.

Este trabalho teve como aporte específico o historiográfico, com base em fontes reveladoras que possibilitaram a compreensão e a valorização do patrimônio imaterial local presente nas práticas religiosas de sujeitos sociais. Tais revelações trazem à tona contribuições significativas para que as reminiscências ancestrais presentes nas práticas 
religiosas de matriz africana se mantenham vivas, ainda que sejam desconhecidas ou não reconhecidas por muitos que professam ser religiosos, mas que, ao longo do tempo, somente conseguem enxergar, conhecer e reconhecer o legado das práticas culturais presentes na imposição eurocêntrica do colonizador.

Por fim, conclui-se que a investigação científica, sobretudo a histórica, tem como algumas de suas premissas identificar, vivificar e compreender as práticas e as ações humanas que sedimentam as argamassas do nosso construto patrimonial histórico-cultural plural, diverso, material e simbólico, oriundo do legado ancestral das práticas religiosas de matriz africana.

\section{REFERÊNCIAS BIBLIOGRÁFICAS}

CASTELLS, M. O poder da identidade. São Paulo: Paz e Terra, 1999.

CEARÁ. Lei no 11.308, de 15 de abril de 1987. Cria o Município de Acarape, desmembrado de Redenção. Diário Oficial do Estado do Ceará, Poder Executivo, Fortaleza, 16 abr. 1987.

DOMINGOS, L. T. A complexidade da dimensão religiosa da medicina africana tradicional. Mneme: Revista de Humanidades, Caicó, v. 15, n. 34, p. 167-189, 2015.

GASPAR, E. D. Guia de religiões populares do Brasil. Rio de Janeiro: Pallas, 2004.

GOMES, A. O. Aquilo é uma coisa de índio: objetos, memória e etnicidade entre os Kanindé do Ceará. 2012. 322 f. Dissertação (Mestrado em Antropologia) - Programa de Pós-Graduação em Antropologia, Universidade Federal de Pernambuco, Recife, 2012.

IPECE - Instituto de Pesquisa e Estratégia Econômica do Ceará. Mapa Básico Municipal. Disponível em: http://www.ipece.ce.gov.br/mapas-municipais/. Acesso em: 3 ago. 2019.

JUCÁ NETO, C. R. Os primórdios da organização do espaço territorial e da vila cearense: algumas notas. Anais do Museu Paulista, São Paulo, v. 20, n. 1, p. 133-163, 2012.

LAKATOS, E. M.; MARCONI, M. A. Fundamentos de metodologia científica. São Paulo: Atlas, 1994.

MARTINS, E. S. Leitura e trabalho pedagógico: trajetórias e experiências de professores. Fortaleza: Seduc, 2011.

MUNDO ESTRANHO. Qual a ligação entre os santos católicos e os orixás? Mundo Estranho, São Paulo, 4 jul. 2018. Disponível em: http://mundoestranho.abril.com.br/materia/qualaligação entreossantoscatólicoseosorixás. Acesso em: 22 abr. 2019.

OLIVEIRA, S. C. Romaria do Bom Jesus da Lapa, prática do catolicismo popular. Fragmentos de Cultura, Goiânia, v. 21, n. 4/6, p. 249-268, 2011. 
ORTIZ, R. A morte branca do feiticeiro negro: umbanda e sociedade brasileira. São Paulo: Brasiliense, 1999.

PUNTEL, J. Comunicação: diálogo dos saberes na cultura midiática. São Paulo: Paulinas: Sepac, 2010.

SAMPAIO FILHO, D. História dos municípios do Ceará. Fortaleza: RBS, 2003.

SANCHIS, P. Percursos de sincretismo no Brasil. Rio de Janeiro: Verj, 2001.

SEGALEN, M. Ritos e rituais contemporâneos. Rio de Janeiro: FGV, 2002.

SILVA, G. S. Benzendores e raizeiros: saberes partilhados na comunidade remanescente de quilombo de Santana da Caatinga - 1910-2011. Revista Mosaico, São José do Rio Preto, v. 3, n. 1, p. 33-48, 2010.

SILVA, P. A. O. História da escravidão no Ceará. Fortaleza: Instituto Histórico, 2002.

XAVIER, A. R.; MACHADO, C. J. S. História e memória de uma professora quilombola: vitrais biográficos, práticas educativas e identificação étnico-racial. Revista da Associação Brasileira de Pesquisadores/as Negros/as (ABPN), Goiânia, v. 9, n. 22, p. 332-348, 2017.

XAVIER, A. R.; VASCONCELOS, J. G. Povo Kanindé de Aratuba-CE: história, afirmação étnico-cultural e educação. Revista Cocar, Belém, v. 12, n. 24, p. 472-500, 2018

\section{FONTES ORAIS}

ABNER, L. Entrevista com Luiz Abner. Paróquia de Acarape-CE, 17 abr. 2019. mp3, 35 min. Disponível no acervo pessoal dos autores, 2019.

KUANZA, C. N. Entrevista com Caçoma Nataniel Kuanza. Igreja Adventista de Acarape-CE, 5 maio 2019. mp3, 30 min. Disponível no acervo pessoal dos autores, 2019.

SILVINO, S. F. Entrevista com Silva Francisco Silvino. Terreiro de umbanda de Acarape-CE, 30 abr. 2019. mp3, 35 min. Disponível no acervo pessoal dos autores, 2019.

Recebido 30/03/2020

Aprovado em 30/04/2020 